\title{
Growth in demand and supply of pulses in India-A normative approach
}

\author{
P. D. Shivagangavva ${ }^{1}$ and B. S. Reddy ${ }^{2 *}$ \\ ${ }^{1}$ Department of Agricultural Economics, University of Agricultural Sciences, Raichur-584104 (Karnataka), INDIA \\ ${ }^{2}$ College of Agriculture, Aland Road, Kalaburagi-585102 (Karnataka), INDIA \\ ${ }^{*}$ Corresponding author. E-mail: bsreddyagecon@gmail.com
}

Received: January 13, 2016; Revised received: May 24, 2016; Accepted: September 30, 2016

\begin{abstract}
The changing scenario of consumption and production of pulses will have significant influence on the demand-supply prospects of pulses in India. The country as whole, production of redgram had increased marginally $(0.45 \%)$ during $1980-2012$ (Overall study period), though there is positive and significant growth in production $(2.86 \%)$ during 1980-90 (Period-I), mainly due to lower growth during 1991-2012(period-II). The significant growth in production $(1.39 \%)$ and productivity $(1.04 \%)$ of bengalgram in the entire period except area $(0.35 \%)$ was observed. However, growth in greengram production $(1.14 \%)$ and productivity $(1.21 \%)$ was found almost similar. In case of blackgram, positive growth rate in area, productivity and production in both the periods have ultimately resulted higher growth rates in the overall period. The growth in total pulses production indicated that growth in area $(-0.10 \%)$ was negative while it was positive both in production $(1.49 \%)$ and productivity $(1.59 \%)$ during period-I. Similar pattern of growth was observed during period-II and in the overall study period. The estimated demand for pulses were 183.62 lakh tonnes over supply of 148.66 lakh tonnes indicating deficit of 34.96 lakh tonnes during $2001-2011$. Further, demand for pulses expected to reach 225.36 and 255.16 lakh tonnes in the year 2020 and 2030 respectively. Whereas, supply of pulses will reach 218.50 and 237.00 lakh tonnes in the same period indicating narrow gap between demand and supply in the future.
\end{abstract}

Keywords: Demand, Gap, Growth, Projection, Pulses, Supply

\section{INTRODUCTION}

Pulses have been cultivated since time immemorial in rain-fed conditions is characterized by poor soil fertility and moisture stress environments. These pulses improve soil health by enriching nitrogen status, longterm fertility and sustainability of the cropping systems (Balappa et al., 2009). Pulses are the primary source of protein for the poor and the vegetarians. it contains 22 per cent of protein. Pulses turn out to be one of the most economical sources of protein for human consumption. The split grains of these pulses are called dal and are excellent source of high quality protein, essential amino and fatty acids, fibers, minerals and vitamins. The total pulses constitute redgram, bengalgram, greengram, blackgram, lentil,horsegram, avare, cowpea and field pea (Sharma et al., 2012).

At the global level pulses are the second most important group of crops after cereals. The global pulses production was 61.5 million tonnes from an area of 70.6 million hectare with an average yield of $871 \mathrm{~kg} / \mathrm{ha}$ during 2011 (Anonymous, 2011). Developing countries contribute about 74 per cent to the global pulses production and the remaining comes from developed countries. India is the largest producer and consumer of pulses in the world contributing around 25-28 per cent of the total global production. About 90 per cent of the global redgram, 75 per cent of bengalgram and
37 per cect of lentil area contributed by India. The country produced 24.78 million tonnes of pulses from 17.21 million ha area, with an average yield of $694 \mathrm{~kg} /$ ha during 2011-12 (Srivastava et al., 2010).

The major producers of pulses in the country are Madhya Pradesh(24\%) followed by Uttar Pradesh (16\%), Maharashtra (14\%), Rajasthan (6\%), Andhra Pradesh $(10 \%)$ and Karnataka (7\%) which together share about 77 per cent of total country's pulse production while remaining 23 per cent is contributed by Gujarat, Chhattisgarh, Bihar, Orissa and Jharkhand. Contribution of pulses in the national food basket has reduced from 17 per cent to 7 per cent (Anonymous, 2011).

Sustained economic growth, increasing population and changing life styles are causing significant changes in Indian food bosket, away from staple food grains towards high value horticultural and animal products (Praduman Kumar et al., 2009). The growth in production and yield lagged behind the population growth rate which has resulted in to a decline in per capita availability of pulses from $65 \mathrm{~g} /$ day/capita during 1965 to $29 \mathrm{~g} / \mathrm{day} /$ capita during 2009 . This changing scenario of consumption and production will have significant influence on the demand supply prospects pulses. Only a few states contribute major share to pulses production in India and there exists a wide variability in their yield across different states of the country and also it is a matter ISSN : 0974-9411 (Print), 2231-5209 (Online) All Rights Reserved (C) Applied and Natural Science Foundation www.jans.ansfoundation.org 
of concern for Indian food-security (Praduman Kumar et al., 2009). This changing scenario of consumption and production will have a significant influence on the demand and supply prospects of food. Keeping this in view, this paper is made an attempt to provide credible estimates of growth in production of pulses and its demand and supply in the past as well as in future.

\section{MATERIALS AND METHODS}

Country as a whole is purposively studied with special focus on Karnataka. The major pulse crops were chosen based on highest area under selected crops. The redgram, bengalgram, greengram, and blackgram together accounts more than 50 per cent of area and production of pulses, hence these four crops were selected for the study. The present study is restricted for a period of 32 years from 1980 to 20112 for all analytical purpose. However for better understanding of growth and development of pulses, their growth rates in area, production and yield were compared for the period from 1980 to 2012 which was further divided in to two periods: (1) period-I 1980 to 1990 (2) period-II 1991 to 2012 .The year 1990 was taken as a cut- off point because of introduction of programme called "Technology Mission on Oilseeds and Pulses" to promote the pulses industry in India wherein, Karnataka state is also covered.

Growth rate analysis: In the present study, compound growth rates in area, production, yield, import and exports of pulses were estimated by specifying the following relationship.

$$
Y_{t}=a b^{t} U_{t}
$$

Where,

$\mathrm{Y}_{\mathrm{t}}=$ area, production, yield, quantity and value of pulses imported and exported in year' $\mathrm{t}$ '

$\mathrm{t}=$ year which takes value 1,2 ,

.. $\mathrm{n}$

$\mathrm{U}_{\mathrm{t}}=$ disturbance term in year' $\mathrm{t}$ '

' $a$ ' and ' $b$ ' are parameters to be estimated.

The equation (1.1) was transformed into log- linear form and written as:

$\log \mathrm{Y}=\log \mathrm{a}+\mathrm{t} \log \mathrm{b}+\log \mathrm{U}_{\mathrm{t}}$

Equation (1.2) was estimated by using ordinary least square (OLS) technique.

Compound growth rate $(\mathrm{g})$ was then estimated by the identity given in equation (1.3).

$$
\mathrm{g}=(\mathrm{b}-1) 100
$$

Where,

$$
\mathrm{g}=\text { estimated compound growth rate in per cent }
$$
per annum.$$
\wedge
$$

$$
\mathrm{b}=\operatorname{antilog} \text { of } \log \mathrm{b}
$$

The standard error of the growth rate was estimated and tested for its significance with ' $t$ ' statistic.

Estimation of demand and supply: Data on population were drawn from population census of 2001 and
2011 and year wise data were worked out by interpolation method between these two censuses.

There are different approaches to workout demand for food grains Viz. (1) household consumption approach; (2) normative consumption approach; (3) behavioural approach; and (4) absorption approach. In the present study based on the availability of data, normative consumption approach was used which is based on the requirement of food and nutrient contents of a balanced diet for a moderately active person life style.

Normative approach determines consumption levels by using normative requirements of pulses as recommended by the National Institute of Nutrition, Hyderabad, @ $14.60 \mathrm{~kg} /$ year/capita as basis and multiplied it with the population to work out the requirement for a particular period. The requirement towards seed, feed and wastage (SFW) assumed to be $12.5 \%$ of the gross output is also added to arrive total requirement.

Demand $=(\mathrm{NIN}$, Hyderabad recommendation $*$ population) $+\mathrm{SFW}$

The study conducted by Rajiv Ratan Lal.et al.,2007, Indian Institute of Pulse Research, Kanpur were worked out 7.95 per cent of output as a post harvest losses during storage and transportation. Accordingly, same per cent of losses $(7.95 \%)$ were taken into consideration. The total supply of pulses were worked out considering net import (export - import) plus total production minus post harvest losses.

Supply=Total production + Net import - Post harvest losses.

Projection of demand and supply: The projections are based on growth in population, change in productivity level. The domestic demand is projected under two scenario of per capita recommendation. The below mentioned scenario's are used by Ali (2012) and Amarender Reddy et al. (2009) for estimating demand for pulses in the study. The domestic demand projections for pulses is arrived at by adding of direct demand (consumption demand=growth in population*per capita recommendation) and indirect demand (requirement of seed, feed, industrial wastage @ $12.5 \%$ of the gross output). Consumption requirement on normative basis recommended by National Institute of nutrition Hyderabad @ $14.60 \mathrm{~kg} /$ year/capita was multiplied with growth in population. Similarly, supply was worked out considering gross output minus 7.95 $\%$ of output as a post harvest losses during storage and transportation. As mentioned in the earlier section, exponential form of the function $Y_{t}=a b^{t}$ is used for estimating future demand and supply of pulses.

\section{RESULTS AND DISCUSSION}

In the state of Karnataka (table-1), growth rate in productivity of redgram showed negative trend while it was positive in both production $(2.02 \%)$ and area (4.21\%) during period-I. However, during period-II growth rate in production $(8.73 \%)$ was significantly 
Table 1. Growth rate of area, production and productivity of pulses in Karnataka and India.

\begin{tabular}{|c|c|c|c|c|c|c|c|}
\hline \multirow[t]{2}{*}{ Crops } & & \multicolumn{3}{|c|}{ Karnataka (\%/annum) } & \multicolumn{3}{|c|}{ India (\%/annum) } \\
\hline & & Period-I & Period-II & Over all & Period-I & Period-II & Over all \\
\hline \multirow[t]{3}{*}{ Redgram } & Area & $4.21 * * *$ & $3.08 * * *$ & $2.05 * * *$ & $2.31 * * *$ & $0.36^{* *}$ & $0.63 * * *$ \\
\hline & Production & 2.02 & $8.73 * * *$ & $4.36 * * *$ & $2.86^{* *}$ & $0.76^{* *}$ & $0.45^{* *}$ \\
\hline & Productivity & -2.09 & $2.73 * * *$ & $0.98^{* * *}$ & 0.54 & 0.39 & 0.18 \\
\hline \multirow[t]{3}{*}{ Bengalgram } & Area & $3.73 *$ & $6.79 * * *$ & $2.63 * * *$ & -1.42 & $1.03 * * *$ & 0.35 \\
\hline & Production & 1.49 & $8.75 * * *$ & $4.64 * * *$ & -0.79 & $1.94 * * *$ & $1.39 * * *$ \\
\hline & Productivity & -0.15 & $2.12 * * *$ & $2.11^{* * *}$ & 0.64 & $0.90 * * *$ & $1.04 * * *$ \\
\hline \multirow[t]{3}{*}{ Greengram } & Area & 0.28 & $3.62 * * *$ & $4.45 * * *$ & $1.96^{* * *}$ & 0.45 & $0.44 * * *$ \\
\hline & Production & $-9.24 * * *$ & 2.15 & $2.11 * * *$ & $2.95 * *$ & 0.2 & 1.14 \\
\hline & Productivity & -0.64 & -1.27 & $-1.64 * * *$ & 1.02 & 0.19 & 1.21 \\
\hline \multirow[t]{3}{*}{ Blackgram } & Area & $4.73 * * *$ & -0.22 & $3.37 * * *$ & $2.20 * * *$ & 0.1 & 1.24 \\
\hline & Production & $7.34 * *$ & $-3.52 * *$ & $2.46 * * *$ & $5.86 * * *$ & 0.24 & $2.85^{* * *}$ \\
\hline & Productivity & 2.46 & $-3.25^{*}$ & -0.87 & $3.59 * * *$ & 0.81 & $2.73 * *$ \\
\hline \multirow[t]{3}{*}{ Total pulses } & Area & 0.14 & 0.91 & $1.09 * * *$ & -0.10 & -0.74 & $-0.45^{*}$ \\
\hline & Production & 0.57 & 0.58 & $1.67 * * *$ & 1.49 & $0.94 * * *$ & $0.86^{* * *}$ \\
\hline & Productivity & 0.72 & 0.58 & $0.69 * *$ & $1.59 * *$ & $0.52 *$ & $0.75 * * *$ \\
\hline
\end{tabular}

Note: Period-I $=1980$ to 1990 , Period-II $=1991$ to 2012 and Over all=1980 to 2012, *** Significant at 10 per cent level, $* *$ Significant at 5 per cent level, * Significant at 1 per cent level

increasing mainly due to significant growth rate in area $(3.08 \%)$ and productivity $(2.73 \%)$. Similarly, the trend for overall period was positive and significant in area $(2.05 \%)$, productivity $(0.98 \%)$ and production $(4.36 \%)$. For the country as whole, the production of redgram had increased marginally $(0.45 \%)$ in the overall study period, though there is positive and significant growth in production $(2.86 \%)$ during period-I, mainly due to lower growth in period-II. Further, growth in area and production were significant in all the periods, while it was positive and non-significant in productivity.
The production $(4.64 \%)$ of bengalgram had increased significantly in the overall period due to positive and significant growth in area $(2.63 \%)$ and productivity $(2.11 \%)$ in Karnataka. Further, growth in productivity was positive and significant in the overall period, even though negative growth was noticed in period-I. The country as whole also showed mixed trend of growth in both the periods. In period-I, negative growth was observed in area $(-1.42 \%)$ and production $(-0.79 \%)$ while it was positive in productivity $(0.64 \%)$. Whereas positive and significant growth rate was noticed in

Table-2. Demand and supply of pulses in Karnataka and India.

\begin{tabular}{cccccccc}
\hline & $\begin{array}{c}\text { Direct de- } \\
\text { mand } \\
\text { (mt) }\end{array}$ & $\begin{array}{c}\text { Indirect de- } \\
\text { mand } \\
(\mathbf{m t})\end{array}$ & $\begin{array}{c}\text { Total De- } \\
\text { mand } \\
(\mathbf{m t})\end{array}$ & $\begin{array}{c}\text { Produc- } \\
\text { tion } \\
(\mathbf{m t})\end{array}$ & $\begin{array}{c}\text { PHL } \\
(\mathbf{m t})\end{array}$ & $\begin{array}{c}\text { Supply } \\
(\mathbf{m t})\end{array}$ & $\begin{array}{c}\text { Gap } \\
(\mathbf{m t})\end{array}$ \\
\hline Karnataka & & & & & & \\
\hline 2001 & 0.77 & 0.09 & 0.86 & 0.75 & 0.06 & 0.69 & -0.17 \\
2003 & 0.80 & 0.07 & 0.87 & 0.57 & 0.05 & 0.52 & -0.35 \\
2005 & 0.82 & 0.12 & 0.94 & 0.95 & 0.08 & 0.88 & -0.06 \\
2007 & 0.84 & 0.15 & 1.00 & 1.23 & 0.10 & 1.14 & 0.14 \\
2009 & 0.87 & 0.14 & 1.01 & 1.10 & 0.09 & 1.01 & 0.00 \\
2011 & 0.89 & 0.13 & 1.02 & 1.06 & 0.08 & 0.98 & -0.04 \\
Overall mean & 0.83 & 0.12 & 0.95 & 0.93 & 0.07 & 0.86 & -0.09 \\
\hline India & & & & & & & \\
\hline 2001 & 15.02 & 1.67 & 16.69 & 13.37 & 1.06 & 12.31 & -4.38 \\
2003 & 15.55 & 2.12 & 17.67 & 16.98 & 1.35 & 15.63 & -2.04 \\
2005 & 16.08 & 1.87 & 17.95 & 14.96 & 1.19 & 13.77 & -4.18 \\
2007 & 16.61 & 2.00 & 18.61 & 16.01 & 1.27 & 14.74 & -3.87 \\
2009 & 17.14 & 2.17 & 19.31 & 17.33 & 1.38 & 15.95 \\
2011 & 17.67 & 2.56 & 20.23 & 20.50 & 1.63 & 18.87 \\
Overall mean & 16.34 & 2.02 & 18.36 & 16.15 & 1.28 & 14.87 \\
\hline
\end{tabular}

Note: 1 . Direct demand = Recommendation of NIN, Hyderabad (@14.60 kg/year/annum)*population, 2. Indirect demand=Seed and feed requirement plus wastage(SFW)@12.5\% of gross output, 3. Total demand = Direct demand plus indirect demand, 4. Supply $=$ Actual production minus post harvest losses(PHL)@7.95\% of gross output, $5 . \mathrm{mt}=$ Million tonnes 
Table 3. Actual and projected demand and supply of pulses during 2020 and 2030.

\begin{tabular}{lccc}
\hline Particulars & $\begin{array}{c}\text { Demand } \\
\text { (Lakh tonnes) }\end{array}$ & $\begin{array}{c}\text { Supply } \\
\text { (Lakh tonnes) }\end{array}$ & $\begin{array}{c}\text { Gap } \\
\text { (Lakh tonnes) }\end{array}$ \\
\hline $\mathbf{2 0 0 1 - 2 0 1 1}$ & & & -0.91 \\
\hline Karnataka & 9.48 & 8.57 & -34.96 \\
India & 183.62 & 148.66 & -0.84 \\
$\mathbf{2 0 2 0}$ & & & -7.14 \\
Karnataka & 11.34 & 11.1 & -0.62 \\
India & 225.36 & 218.50 & -18.16 \\
$\mathbf{2 0 3 0}$ & 12.66 & 12.02 & \\
Karnataka & 255.16 & 237.00 & \\
India & & & \\
\hline
\end{tabular}

Note: For the period 2001-2011 average quantity is worked out

area, production and productivity in period-II and ultimately resulted positive and significant growth rate in production $(1.39 \%)$ and productivity $(1.04 \%)$ in the entire study period except area $(0.35 \%)$.

In case of green gram, Karnataka state showed mixed growth trend in both the periods. In period-I negative growth rate was observed in production $(-9.24 \%)$ and productivity $(-0.64 \%)$ while it was positive in production $(2.15 \%)$ in period-II, though there is negative growth in productivity $(-1.27 \%)$. The growth in area $(4.45 \%)$ and production $(2.11 \%)$ were positively significant in the overall period eventhough negative growth in area(-1.64\%) was noticed. The country as whole showed positive growth in area, production and productivity in all the periods. It is worth noting that growth rate in production $(1.14 \%)$ and productivity $(1.21 \%)$ was found almost similar. However, growth in area $(0.44 \%)$ was found significantly lower.

Black gram showed mixed trend in Karnataka state, whereas the Country as whole showed positive growth rate in area, productivity and production in both the periods have ultimately resulted higher growth rates in the overall period. Similar studies conducted by Balappa Shivaraya (2009) on growth performance of redgram in Karnataka state indicated positive growth in pre liberalised period compared to post liberalised period. Further, Bindu Kumar (2006) conducted study on Pre and post WTO era: Changes in pulses economy in Karnataka found similar findings wherein growth in area, productivity and production of redgram were negative during pre-liberalization period turned out to positive and significant increase during post liberalization period.

In case of total pulses growth in area, production and productivity were positive and significant in both before (Period-I) and after (Period-II) in Karnataka. Introduction of programme called "Technology Mission on Oilseeds and Pulses (TMOP)" to promote the pulses industry in India wherein, Karnataka state has also covered. The country as whole, growth in area(-0.10\%) was negative while it was positive both in production $(1.49 \%)$ and productivity $(1.59 \%)$ during period-I. However during period-II, growth in production
$(0.94 \%)$ and productivity $(0.52 \%)$ were positive and significant, even though growth in area $(-0.74 \%)$ was negative. It is worth noting that pulses production was significantly increased mainly because of intensive promotional programs launched in the country including release of improved varieties like Maruti, TS-3R, BSMR, JG-11, TAU-1, T-9, Pusa Bisaki etc., implementation of accelerated pulse production programmes, awareness about package of practices for higher yield by the Agricultural Universities and Pulse Research Station and ICRISAT. The growth rate in yield in all the pulses increased in Karnatak and country as a whole during entire study period. The growth in yield in general found to be lower indicating the scope for improving the productivity of all pulses. The study conducted by Balappa Shivaraya (2008) on growth in yield and resource use efficiency in redgram under IPM technology in Gulbarga district revealed that growth in redgram yield was significantly lower compared to area during study period (1990 to 2007). Similarly, Dixit et al. (2012) conducted study on growth performance and Potential of wastelands ( degraded forest(scrub dominated), under-utilized forest (agriculture), degraded pastures /grazing land and degraded land under plantation crops) for mixed farming system indicated marginal growth in yield. Therefore, to encourage the farmers to increase production of pulses, the necessary infrastructure along with improved production technology need to be developed.

Demand and supply of pulses: Karnataka is one of the important pulses growing state and it contributes around seven per cent of the total pulses production in the country. It could be seen from the table- 2 that average mean value of demand for pulses were 0.95 million tonnes over supply of 0.86 million tonnes indicating deficit of 0.09 million tonnes. Of the total demand, direct demand for consumption was 0.83 million tonnes and indirect demand for seed and feed requirement and wastage were to the tune of 0.12 million tonnes per annum.

The findings of the below mentioned results are in line with Praduman Kumar (1998) conducted study on food demand and supply projections for India, Bhalla (2001) conducted study on demand and supply of food 
grains by 2020: Towards hunger free, Hanchante and Dyson (2004) studied the prospects for food demand and supply in India and Mittal (2008) analysed the demand-supply trends and projections of food in India revealed that demand for food grains will be more than its supply. The country as a whole revealed that total demand increased from 16.69 million tonnes in 2001 to 20.23 million tonnes in 2011. The consumption demand (Direct demand) increased from 15.05 million tonnes to 17.67 million tonnes and seed and feed requirement and wastage (Indirect demand) were increased from 1.67 million tonnes to 2.56 million tonnes during 2001 to 2011 respectively. On the other, supply of pulses have been increased from 12.31 million tonnes in 2001 to 18.87 million tonnes in 2011 indicating deficit of pulses to the tune of 2.0 to 4.0 million tonnes. The overall mean value of demand was 18.36 million tonnes per annum during study period. However, supply was only 14.87 million tonnes indicating deficit of 3.49 million tonnes per annum.

Projected demand and supply of pulses: It is important to assess the feasibility of achieving nine per cent economic growth because agriculture is constrained by a numbers of factors of which supply and demand constraints are crucial ones. The imbalance between supply and demand impacts the prices and profitability, which call for policy intervention and planning to tackle situation in future. Thus, the projections on demand side and supply side become very relevant to make policy interventions in the country in general and Karnataka in particular.

The demand and supply projection of pulses in Karnataka and Country as a whole were predicted for the year 2020 and 2030. As evident from the table- 3 that the projected demand for pulses in Karnataka state is expected to reach 11.34 and 12.66 lakh tonnes in the year 2020 and 2030 respectively. Whereas, supply of pulses will reach 11.10 and 12.02 lakh tonnes in the same period indicating narrow gap between demand and supply. Similarly, country as a whole, total pulses requirement worked out to be 225.36 and 255.16 lakh tonnes in the year 2020 and 2030 respectively. In contrary to this projected supply will be only 218.50 and 237.00 lakh tones during same period. Similar results were reported by Mittal (2008) who conducted study on Demand-supply trends and projections of food in India, Amarender Reddy (2009) on Pulses production technology, Ramesh Chand (2009) on Demand for foodgrains during $11^{\text {th }}$ plan and towards 2020, Srivastava et al. (2010) on Diagnosis of pulses performance of India, Rajesh Kumar (2012) on Trends in area, production and productivity of major spices in India and Ali (2012) on Carrying capacity of Indian agriculture: pulse crops.

Thus, we need to have necessary policy initiatives to increase the supply in the long run. The country will need to focus on productivity enhancement for bridg- ing gap. There is also need to adopt modern technology in processing to increase the recovery percentage. This play important role in the food security of the country and also helps to minimize the import.

\section{Conclusion}

Growth in production of total pulses increased significantly over the study period (1980-2012) at the national level. Among the pulses, greengram and blackgram registered higher growth in at the national level while redgram and bengalgram registered higher growth in Karnataka state as a whole. The increase in the pulses production was mainly due to increase in consumption demand, better prices, higher income with use of improved varieties and availability of production technology in recent years might have encouraged growth in pulse production. However, estimated demand for pulses were 183.62 lakh tonnes over supply of 148.66 lakh tonnes indicating deficit of 34.96 lakh tonnes. Further, demand for pulses expected to reach 225.36 and 255.16 lakh tonnes in the year 2020 and 2030 respectively. Whereas, supply of pulses will reach 218.50 and 237.00 lakh tonnes in the same period indicating gap between demand for and supply of pulses is expected to widen in future at the national level. Thus, we need to have necessary policy initiatives to increase the supply in the long run.

\section{REFERENCES}

Ali, M. and Gupta, S. (2012). Carrying capacity of Indian agriculture: pulse crops. Cur. sci., 102:874-881

Amarender Reddy (2009). Pulses production technology: Status and way forward. Econ. and Pol. Weekly, 14(2): $52-58$

Anonymous (2011). Balancing demand and supply during 12th five year plan- report of working group on food grains. Crops Division Department of Agriculture and Cooperation, Ministry of Agriculture Krishi Bhawan, New Delhi, pp 25-56

Balappa Shivaraya, Hugar, L. B. and Olekar, J. N. (2008). Growth performance of redgram in Karnataka state. Agril. Banker, 23(2): 30-33

Balappa Shivaraya, Hugar, L. B. and Hiremath, G. K. (2009). Production performance and resource use efficiency in redgram under integrated pest management technology in Gulbarga district. Karnataka J. Agric. Sci., 11(3): 712-716

Bhalla, G.S. (2001). Demand and supply of food grains by 2020: Towards hunger free. Chanda Publishing House, New Delhi.

Bindukumar (2006). Pre and post WTO era: Changes in pulses economy in Karnataka. M. Sc. (Agri.) Thesis, Univ. Agric. Sci., Dharwad.

Dixit, A. K., Singh,M.K., Reddy, B. S. and Manohar, N. S. (2012). Potential of wastelands for mixed farming system in India. Range Management and Agroforestry, 33(2) : 118-122

Hanchante and Dyson, T. (2004). Prospects for food demand and supply in India, The book of twenty first century Oxford Univ., London. 
Mittal, S. (2008). Demand-supply trends and projections of food in India. Indian Council for Research on International Economic Relations (ICRIER), Working Paper :4-23

Praduman Kumar. (1998). Food demand and supply projections for India. Agric. Econ., Policy Paper: 32-28

Praduman Kumar, Joshi, P. K. and Birthal, P. (2009). Demand projections for food grains in India. Agric. Econ. Res. Rev., 22(2): 237-243.

Ramesh Chand (2009). Demand for foodgrains during $11^{\text {th }}$ plan and towards 2020. National Center for Agric. Econ. Policy Res. Paper, 1-4

Rajiv, R. and Verma, P. (2007). Post harvest management. Indi- an Institute of Pulses Research Kanpur report:25-32.

Rajesh Kumar. (2012). Future scenario of food grains: A case study for gap between demand and supply, Socioeconomic voices report, : 1-8

Sharma, O. P., Bambawale, O. M., Yelshetty, S., Patil, B.V., Gopali, J.B., Bhagat, S., Khullar, M., Neeraja, A., Rachappa V. and Patil V.M. (2012). Innovative approach in sustainable production of pigeonpea and chickpea. NCIPM Publication report, 11-55

Srivastava, S. K., Sivaramane, N. and Mathur, V.C. (2010). Diagnosis of pulses performance of India. Agric. Econ. Res. Rev., 23 (4): 137-148 